\title{
CIDADANIA AMBIENTAL: A UTILIZAÇÃO DE CURTAS- METRAGENS SOCIOAMBIENTAIS COMO FERRAMENTA PARA A EDUCAÇÃO AMBIENTAL CRÍTICA
}

\author{
Denise Gallo Pizella ${ }^{1}$ \\ João Vitor de Souza Xavier²
}

Resumo: Com o auxílio de curtas-metragens, este artigo teve como objetivo identificar as percepções de estudantes do Ensino Médio no município de llha Solteira (SP) a respeito dos atores sociais responsáveis pela busca de soluções aos problemas socioambientais, partindo do pressuposto de que um cidadão ativo é aquele que atua em conjunto com o Poder Público na transformação da sociedade. Como resultados, a maioria dos estudantes manifestou, durante as intervenções realizadas, uma visão de cidadania passiva, em que somente a sociedade, ou o Poder Público isoladamente são os promotores de mudanças sociais em torno da sustentabilidade ambiental. Deste modo, se vê a necessidade da adoção de uma Educação Ambiental Crítica no espaço formal de ensino, pelo seu caráter emancipatório.

Palavras-chave: Vertentes de Educação Ambiental; Cidadania Ativa; Espaço Formal de Ensino.

\footnotetext{
1 Universidade Estadual Paulista "Júlio de Mesquita Filho". Faculdade de Engenharia de llha Solteira. Departamento de Biologia e Zootecnia. E-mail: denise.gallo@unesp.br.

2Universidade Estadual Paulista "Júlio de Mesquita Filho". Faculdade de Engenharia de llha Solteira. Departamento de Biologia e Zootecnia. E-mail: joaovitor.sx@hotmail.com.
} 


\section{Introdução}

O modelo de desenvolvimento econômico vigente é excludente do ponto de vista social e esgotante dos recursos naturais, provocando poluição nos diversos compartimentos dos ecossistemas (solo, ar, água, fauna e flora) e ultrapassando a capacidade de suporte do meio. Tal degradação se origina pela não incorporação da variável ambiental no desenvolvimento das diversas atividades humanas, com seu comprometimento atual e futuro (MARQUES, 2017).

Neste sentido, para além do papel do Estado como agente implementador e fiscalizador de políticas públicas que considerem as questões ambientais, se faz necessária uma educação que, tanto no âmbito informal como formal, possibilite que a população reconheça os problemas ambientais existentes em seu entorno e no globo como um todo e busque, de forma participativa, identificar e implementar possíveis soluções para evitar e minimizar os problemas gerados (MARICATTO, 2002). A Educação Ambiental (EA) é, no tempo moderno, uma importante ferramenta para um futuro mais sustentável e a principal maneira de formar cidadãos que pensem criticamente a respeito da realidade social, econômica, ambiental e cultural na qual se inserem, buscando modificar as estruturas de poder que conduzem à exclusão social e aos problemas ambientais vigentes, tornando-se cidadãos ativos em suas comunidades. $\mathrm{Na}$ instituição escolar, qual seja, em um ambiente educacional formal, existem formas diversas para se inserir a temática ambiental nos currículos escolares, seja no desenvolvimento de atividades artísticas, experiências práticas, atividades fora do ambiente escolar, por meio de projetos, dentre outros (SATO; PASSOS, 2002; FERREIRA, 2013).

Entende-se como imprescindível na proposição de intervenções nas escolas em Educação Ambiental, a participação dos alunos, já que esta possibilita uma aprendizagem política, indutora da gestão democrática nos diversos ambientes em que o aluno se insere, seja a escola, o lar, a comunidade ou a cidade. Por meio da participação, é possível vincular educação à cidadania, ou seja, ao exercício da autonomia do indivíduo de modo responsável para com a coletividade (LOUREIRO, 2004).

Segundo Tristão (2004), a temática ambiental é facilmente relacionada aos temas apresentados aos alunos em sua grade tradicional de disciplinas, mas, por apresentar uma natureza interdisciplinar, é mais bem trabalhada por meio de projetos ou atividades extracurriculares, pois não é possível inseri-la na estrutura curricular, em uma única disciplina. Neste sentido, segundo Rosa (2000) e Cruz e Fernandes (2013), o emprego de documentários e animações em sala consiste em uma ferramenta para trabalhar a Educação Ambiental, devido ao apelo às estruturas emocionais do aluno, possibilitando a aprendizagem de conteúdos curriculares apresentados em sala-de-aula. A autora ressalta que, além disto, "a quebra do ritmo provocada pela apresentação de um audiovisual é saudável, pois altera a rotina da sala de aula" (ROSA, 2000, p. 39). Neste sentido, Gava e Xavier (2008), apontam para 
a utilização da ferramenta audiovisual visando que os alunos possam articular diversas visões de mundo de modo estimulante, pelo fato de esta possuir uma linguagem própria e cotidiana. Já para Linhares e Reis (2013), o emprego de material audiovisual é um importante recurso para a promoção da discussão de assuntos científicos em sala de aula, para além de seu uso como um complemento de informações transmitidas pelos docentes.

Além de possibilitar um melhor tratamento dos conteúdos relacionados à temática ambiental, o uso de recursos audiovisuais permite que o aluno recorra aos conhecimentos que são adquiridos cotidianamente, em seu entorno, no momento de refletir sobre os temas abordados, já que a linguagem empregada nos mesmos é de uso popular e os temas são desenvolvidos de modo interativo, em relação ao material didático normalmente empregado em sala de aula (ROSA, 2000). Para Vieira e Rosso (2011), a utilização de documentários e filmes é adequada para o tratamento de questões ambientais, em função do caráter crítico da Educação Ambiental, visto que possibilitam a integração de conhecimentos acerca de um problema complexo em termos dos processos naturais e sociais que se encontram em sua gênese e solução. Já para Menezes e Duarte (2007), a ferramenta audiovisual potencializa a capacidade de os alunos refletirem de forma crítica sobre temas socioambientais, por mobilizarem experiências adquiridas ao longo da vida.

Outros autores também apontam para a utilização desta ferramenta no Ensino de Ciências e em outras disciplinas curriculares e extracurriculares, tais como Maestrelli e Ferrari (2006), Lasara (2013), Lima (2013) e Neves (2013). Para Napolitano (2010, p.11) "trabalhar com o cinema em sala de aula é ajudar a escola reencontrar a cultura ao mesmo tempo cotidiana e elevada, pois o cinema é o campo no qual a estética, o lazer, a ideologia e os valores sociais mais amplos são sintetizados numa mesma obra de arte".

Tendo em vista o emprego de curtas-metragens para a condução de debates sobre problemas socioambientais e a importância de uma cidadania ativa para sua solução e mitigação, este artigo tem como objetivo identificar o posicionamento de estudantes do Ensino Médio como cidadãos ativos ou passivos, em uma instituição escolar no município de llha Solteira, a noroeste do estado de São Paulo.

\section{Referencial Teórico}

\section{As vertentes da Educação Ambiental}

A Educação Ambiental perpassa por diversas disciplinas do saber. Ela surge na intenção de reverter ou de diminuir os processos degradantes que os seres humanos produzem sobre o meio. Segundo Sorrentino (1991) é necessária a articulação de ações de Educação Ambiental baseadas nos conceitos de ética e sustentabilidade, valoração da identidade cultural e da diversidade, mobilização, participação e práticas interdisciplinares. Ou seja, para se mudar a forma de pensar e agir em torno da questão ambiental, se

revista brasileira educação ambiental 
deve começar pela educação, que deve ser ofertada de maneira interdisciplinar. Sendo assim, para que seja de qualidade, deve ser integrada com um conjunto de especialistas de diferentes áreas para tratar um assunto abrangente, onde a parte faz o todo e o todo faz a parte (MORIN, 2006).

A Educação Ambiental possui diversas tendências ou vertentes, com finalidades distintas. A Educação Ambiental Conservacionista é centrada na conservação dos recursos, como a água, solo, energia, plantas, animais, patrimônio genético, patrimônio construído, entre outros. Aqui se encontra a preocupação com a administração do meio ambiente para a conservação dos recursos (SAUVÉ, 2005). A Educação Ambiental Biológica é aquela ligada ao meio científico, na qual atuam "vários autores ou pedagogos que se interessam pela Educação Ambiental a partir de preocupações do âmbito da didática das ciências ou, mais ainda, de seus campos de interesse em ciências do meio ambiente" (SAUVÉ, 2005 p.23).

A Educação Ambiental Comemorativa aborda os temas ambientais em datas voltadas à conscientização ambiental (Dia da Árvore, Dia da Água, Semana do Meio Ambiente), inseridas na cultura ocidental. Segundo Sauvé (2005, p.25), tal vertente "corresponde a um meio de vida, com suas dimensões históricas, culturais, políticas, econômicas, estéticas etc. Não pode ser abordado sem se levar em conta sua significação, seu valor simbólico".

A Educação Ambiental Crítica, segundo Guerra e Abílio (2006), busca a adoção de práticas interdisciplinares em EA visando o desenvolvimento da consciência crítica das pessoas a partir da informação sobre os problemas ambientais e seus modos de superá-los por meio da participação da comunidade afetada, visando a manutenção dos recursos ambientais e da justiça ambiental. Assim, se tem uma concepção de EA relacionada à "crítica social" que, por sua vez, nasce da "análise das dinâmicas sociais que se encontram na base das realidades e problemáticas ambientais: análise de interações, de posições, de argumentos, de valores explícitos e implícitos, de decisões e de ações dos diferentes protagonistas de uma situação" (SAUVÉ, p.30).

A Educação Ambiental Crítica, vertente utilizada neste artigo, se baseia no ideário da democracia e emancipação humana, rompendo com uma educação meramente tecnicista, difusora e conteudista, trazendo à tona a construção social. Paulo Freire, referência na concepção de uma educação crítica, diz que ela é formadora de cidadãos emancipados. Segundo Carvalho (2004), a respeito de Paulo Freire, "as metodologias de alfabetização baseadas em temas e palavras geradoras, por exemplo, buscam religar o conhecimento do mundo à vida dos educandos para torná-los leitores críticos do seu mundo" (CARVALHO, 2004, p.18). Então, o conhecimento do mundo informa e forma pessoas, capacitando-os à cidadania, que só é capaz de acontecer graças às práxis dos movimentos sociais e da atuação dos profissionais da área (REIGOTA, 2008). 
Assim como Guerra e Abílio (2006), definir Educação Ambiental crítica é falar sobre Educação, dando-lhe uma nova dimensão: a dimensão ambiental, contextualizada e adaptada à realidade interdisciplinar, vinculada aos temas ambientais locais e globais. O Poder Público é importante neste sentido, ao definir tanto os conteúdos didáticos quanto ao possibilitar a participação da população nas tomadas de decisão, como uma forma de fortalecer sua corresponsabilidade na fiscalização e no controle dos agentes de degradação ambiental, dando suporte à cidadania ambiental, na medida em que o indivíduo não se ausenta de sua responsabilidade para questões socioambientais, seja por desinformação ou por falta de percepção ou consciência.

Portanto, a Educação Ambiental pode ser trabalhada como um processo que permite $o$ despertar da consciência crítica a respeito da conservação dos recursos naturais de modo compatível com o bem-estar socioeconômico da população, promovendo o desenvolvimento sustentável. Neste sentido, Jacobi (2003, p. 198) aponta que a sustentabilidade deva "reconsiderar aspectos relacionado à equidade, a justiça social e a própria ética dos seres vivos", já que seu intuito é promover uma mudança nos padrões de uso dos bens ambientais dentro do seu limite, para o bem-estar coletivo.

\section{A Educação Ambiental como promotora da cidadania.}

A Educação Ambiental pode ser concebida como um veículo promotor da cidadania ambiental, na qual o indivíduo se reconhece como um ser pertencente a uma coletividade humana dotada de direitos e deveres para com sua espécie e os demais elementos do planeta. Isto se dá pela busca em compreender a forma como o homem se relaciona com seu meio, em termos dos valores equidade, justiça, cidadania, democracia e conservação ambiental, condicionados às diversas formas de conhecimento existentes. Deste modo, duas perguntas pertinentes podem ser feitas em relação à cidadania: "Como surge o cidadão, historicamente?" e "De que modo a Educação Ambiental pode promover a cidadania ambiental?". Tais questões serão abordadas neste item.

Segundo Pinsky (2015) a construção da cidadania é historicamente condicionada. Por meio dos pensadores iluministas e da Revolução Francesa, no século XVIII, foram conquistados os direitos de primeira geração, quais sejam: direito à vida, à propriedade, à liberdade e a igualdade. No final do século XIX e início do século XX, por meio dos pensadores socialistas (de vertente anarquista e comunista) e dos movimentos sociais por direitos coletivos inspirados em seus ideários, foram conquistados os direitos de segunda geração, ou seja, o descanso semanal, a jornada de trabalho de oito horas ao dia e a carteira assinada (direitos trabalhistas), à seguridade social, à assistência aos desamparados, à educação, habitação, saúde e à infância.

Ainda na segunda metade do século XX foram conquistados os direitos de terceira geração, que são aqueles ligados e consagrados pelos princípios da solidariedade, do direito ao desenvolvimento ou progresso dos países, ao meio 
ambiente ecologicamente equilibrado, à autodeterminação dos povos, entre outros. Esta dimensão de direitos se consagra em uma titularidade difusa, para além da coletiva, incluindo as gerações futuras (DIÓGENES, 2018).

Com as Revoluções Americana e Francesa, surgiu a ideia de liberdade para o indivíduo, proveniente do liberalismo. Tal ideia estabeleceu uma forma legal de o indivíduo não ser limitado pelo Estado, mas não consagrou a liberdade aos negros escravizados e nem o sufrágio universal. Para Karnal (2015), a forma como os direitos de primeira geração se deu nos EUA, pautada pela liberdade do indivíduo e também na livre iniciativa mercadológica, conduziu a uma filosofia de vida baseada na prosperidade, onde o sucesso financeiro do indivíduo o distingue.

Já na França, segundo Odalia (2015), o Estado absolutista, que se apresentava em três estratos sociais (nobreza, alto clero e plebeus) onde havia privilégios para uma minoria de pessoas e um estado de miserabilidade aos demais, culminou com a Revolução Francesa de 1789, de onde surgiu a "Declaração dos Direitos do Homem", estabelecendo que "os homens nascem e permanecem livres e iguais em direitos" (ODALIA, 2015, p.167).

Os direitos sociais ou coletivos surgem por meio de movimentos trabalhistas no período da Revolução Industrial, que reivindicavam tanto o direito ao trabalho como de condições adequadas para seu desempenho, como salubridade nas indústrias, diminuição da jornada diária de trabalho, direito ao descanso semanal, ao registro do trabalhador e o término do trabalho infantil (SINGER, 2015).

Para Singer (2015), as denominadas "Leis Fabris" foram os primeiros direitos sociais legalmente conquistados na era do capitalismo industrial, culminando na limitação de idade para o trabalho infantil e na jornada de trabalho. No entanto, assim como todas as gerações de direitos, as lutas por direitos coletivos se seguiram, levando inclusive à criação da Organização Internacional do Trabalho (OIT), entre os séculos XIX e XX. Segundo Singer (2015) a OIT tinha e tem a finalidade de promover a negociação entre os governos, trabalhadores e empregadores de seus países membros, de modo a garantir que o trabalho se dê de forma digna. Segundo lurconvite $(2018$, p. 2) os direitos sociais "reclamam do Estado uma ação que possa proporcionar condições mínimas de vida com dignidade", sempre buscando diminuir as desigualdades sociais e, notadamente, proporcionando proteção aos mais fracos.

A cidadania ambiental, por sua vez, inclui em si as três gerações de direitos, os quais são objeto de luta constante quanto ao acesso equitativo dos bens provenientes de um meio ecologicamente equilibrado, sem que o ônus da degradação ambiental seja dado a uma parcela da população em detrimento de outra. Portanto, para que haja cidadania ambiental, é necessário o tratamento das injustiças ambientais. 
Para se definir um cidadão ativo ou passivo, parte-se do pressuposto de RAMOS (2008) sobre a ideia de participação e de corresponsabilidade na articulação de pessoas envolvidas em ações coletivas. Desta forma, define-se cidadania ativa como uma visão de mundo e a ação de cidadãos que, além de exercerem a reivindicação constante de direitos, também cumprem com seus deveres perante o Estado, havendo uma maior permeabilidade da sociedade civil no Estado. Tal participação direta no exercício do direito político requer, pelos canais institucionais, participação nas decisões e nas apresentações de políticas públicas de iniciativas populares. A cidadania passiva, por sua vez, é aquela em que os direitos são outorgados pelo Estado, tornando o cidadão por ele tutelado (BENEVIDES, 1994).

\section{Metodologia}

Em relação à natureza deste artigo, de acordo com Severino (2007), se trata de uma pesquisa de abordagem qualitativa e quantitativa.

A pesquisa foi realizada em uma instituição escolar de ensino privada do município de llha Solteira, SP, que foi tratada anonimamente, nos três anos do Ensino Médio. As etapas utilizadas foram as seguintes:

1.1 Foram exibidos quatro curtas-metragens relacionados à temática socioambiental (áreas verdes urbanas; água; floresta Amazônica e agroecologia) nos três anos do Ensino Médio da instituição em questão, em horários de aulas disponibilizados pelos docentes (aulas com 50 minutos cada). De modo a desenvolver as intervenções em sala, se buscou documentários com cerca de 10 minutos de duração. Após a exibição dos curtas-metragens, foram realizados breves debates com os estudantes (com aproximadamente 25 minutos de duração), acerca do tema tratado, onde o pesquisador atuou como mediador, incentivando a participação por meio de perguntas indutoras, permitindo o debate aberto entre os estudantes. Posteriormente, os estudantes foram convidados a responder um questionário contendo perguntas direcionadas ao tema em questão, de modo a possibilitar uma identificação sobre a concepção de cidadania ambiental dos estudantes. Novamente, as respostas foram escritas sem a interferência do mediador. Para que os estudantes tivessem um tempo adequado para formular suas respostas, cerca de 20 minutos foram destinados a esta ação.

1.2 As respostas foram analisadas seguindo o método de análise de conteúdo de Bardin (2011) e tendo por referencial quanto às categorias de cidadania ativa e passiva, Benevides (1994). Deste modo, foram elaboradas quatro categorias de respostas, quais sejam: "Poder Público", cuja categoria representa as respostas dos estudantes que se posicionaram de forma passiva frente aos problemas socioambientais, posto que demonstraram aguardar soluções somente por parte do 
Estado, sem envolvimento da sociedade civil. Outra categoria que representa a cidadania passiva foi denominada de "Indivíduo/Sociedade", cujas respostas mostraram que os atores responsáveis por tratar dos problemas ambientais são os indivíduos e/ou a sociedade, sem intervenção do Estado. A categoria "Sociedade e Poder Público" representa a cidadania ativa, em que os posicionamentos dos estudantes se deram no sentido do envolvimento da sociedade civil em conjunto com o Estado na busca de soluções aos problemas socioambientais. A categoria "Outros", por sua vez, representa respostas cujas características não se alinharam com as categorias anteriores.

Tendo em vista que a vertente Crítica de Educação Ambiental é a que proporciona ao indivíduo uma relação dialética com o meio do qual faz parte, levando-o à reflexão sobre as raízes dos problemas socioambientais e da corresponsabilidade da sociedade civil e do Poder Público em tratá-los, as respostas dos estudantes foi interpretada segundo as vertentes de EA segundo Guerra e Abílio (2006), quando possível, apesar de não ser o tema central do artigo.

Os resultados se deram de acordo com o curta-metragem analisado e as categorias apresentadas em termos quantitativos, por meio de gráficos, e ilustradas com a transcrição das respostas dos estudantes.

\section{Resultados e Discussão}

\section{Análise da percepção de cidadania pelos estudantes: curta metragem "Rio Resiliente: Áreas verdes urbanas"}

O primeiro tema trabalhado nas salas dos três anos do Ensino Médio foi "Áreas verdes Urbanas", por meio do curta-metragem "Rio Resiliente: Áreas Verde Urbanas", produzido pela MULTIRIO (Empresa Municipal de Multimeios da Prefeitura do Rio de Janeiro), que desenvolve produções educativo-culturais voltadas à comunidade escolar (CINEMA E MEIO AMBIENTE, 2017). O documentário aborda a importância de se construir uma cidade mais harmônica com os bens naturais. Tal relação mais harmônica beneficia os seres-humanos, possibilitando um espaço mais belo esteticamente e com respeito aos aspectos ecológicos do meio (BARGOS; MATIAS, 2011).

O curta-metragem enfatiza a necessidade da manutenção de praças, vegetação ciliar, jardins verticais e telhados verdes no ambiente urbano, por afetarem diretamente a qualidade de vida da população através das funções social, estética, ecológica e educativa que exercem.

Para a análise da percepção dos estudantes acerca da valoração das áreas verdes urbanas e dos responsáveis por sua conservação, se questionou aos estudantes: 
"Apresente algumas medidas a ser adotadas para a conservação e até mesmo o aumento das áreas verdes no meio urbano da sua cidade?".

As respostas foram categorizadas e podem ser apresentadas, em termos quantitativos, pela Figura 1 a seguir:

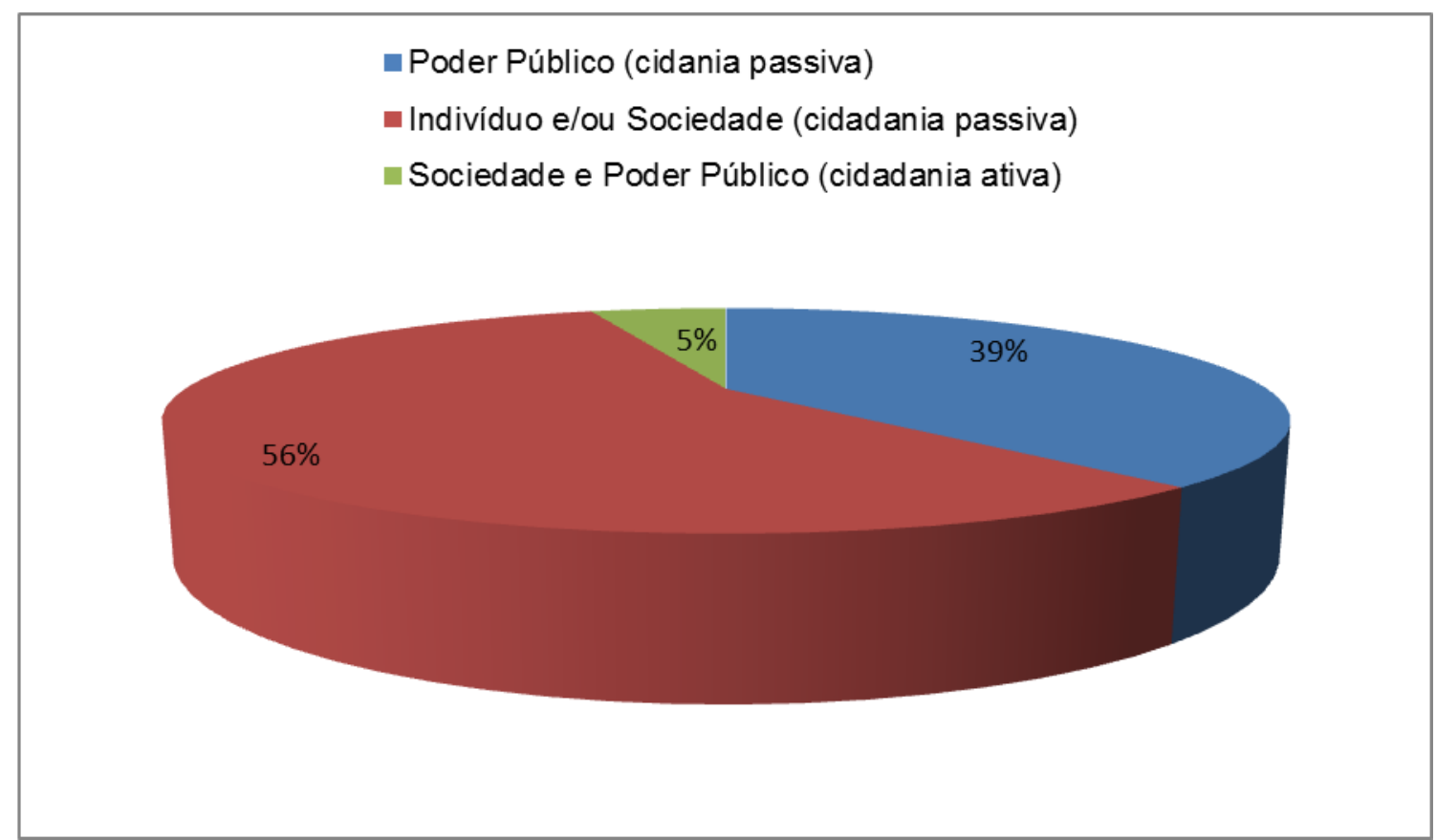

Figura 1: Categorização das respostas dos estudantes no curta-metragem "Rio Resiliente: Áreas Verdes Urbanas". Fonte: Autoria própria.

Por meio da Figura 1, se observa que a categoria "Poder Público" apresentou, em conjunto com "Indivíduo e/ou Sociedade", que caracterizam uma visão de cidadania passiva, $95 \%$ das respostas dos estudantes, enquanto que somente $5 \%$ apresentaram uma concepção de cidadania ativa. No entanto, se percebe que a maioria das respostas atribuiu à sociedade a solução do problema apresentado.

$\mathrm{Na}$ análise das escritas apresentadas pelos estudantes, percebe-se uma visão de tutela dos cidadãos pelo Estado, caracterizando uma percepção de cidadania passiva. Tais estudantes relacionaram a responsabilidade do Estado em fornecer, por exemplo:

Projetos de cuidados e preservação dessas áreas. Campanhas para a expansão dessas áreas por meio da plantação de novas espécies, entre outros. 
Na categoria de cidadania passiva "Indivíduo e/ou Sociedade", percebese a visão também de uma Educação Ambiental Conservacionista, como apresentada pelo Aluno 1.2:

Não jogar lixo, não queimar, não desmatar, não poluir.

Para o mesmo curta-metragem, se observou algumas respostas que indicaram uma ideia de cidadania ativa, aquela que se define como a conquista de direitos, por meio de reinvindicação conjunta da sociedade com o Poder Público. Tal percepção pode se dar no caso deste estudante (Aluno 2.7):

Preservação, pessoas plantando mais árvores. Exigir áreas verdes em relação à política.

Nesta fala, percebem-se duas vertentes de Educação Ambiental. De um lado a ideia equivale a uma Educação Ambiental Conservacionista e, por outro lado, "exigir áreas verdes em relação à política" denota um viés crítico de que o indivíduo não atribui o papel do cuidado ao meio somente aos indivíduos, mas também ao Estado, cujos representantes devem ser chamados a agir em prol da concretude deste direito. No discurso, ele se insere na corresponsabilidade de cobrar do Estado seus direitos, como no exemplo apresentado a seguir do Auno 1.1:

Cobrança da população ao governo local e regional, e também uma mudança geral dos hábitos da população.

Pelo número de respostas de cada categoria, se observa que os estudantes são poucos participativos ativamente na sociedade, sendo possível inferir que acreditam ser dever somente do Poder Público em implantar áreas verdes urbanas, onde a sociedade civil deve somente ser "conscientizada" quanto à sua conservação, ou seja, há a tutela do Estado pelos indivíduos. Em sua grande maioria, acreditam que a conservação destes meios está nas mãos dos indivíduos, que os depredam pela ausência desta consciência que, magicamente, deve ser adquirida pela sociedade. Neste sentido, se chama a atenção para outra fala característica de uma percepção de cidadania passiva (Aluno 1.11):

Ações para o aumento ou manutenção de áreas verdes, vindas das pessoas e pequenas e grandes empresas.

Por meio desta resposta, nota-se que a responsabilidade de fiscalização e controle dos agentes da degradação ambiental é dos indivíduos e de empresas, trazendo à tona a importância das iniciativas empresariais sem uma contextualização sobre sua atuação no que se refere ao papel do Estado. 


\section{Análise da percepção de cidadania pelos estudantes: curta-metragem "Rios Voadores"}

O curta-metragem "Rios Voadores", uma iniciativa da Petrobrás, tem por objetivo discutir a relação entre a Floresta Amazônica e o fornecimento de água doce para as regiões centrais e do sudeste brasileiro por meio de chuvas, sendo que a falta deste fenômeno pode ocasionar prejuízos socioambientais e econômicos (CINEMA E MEIO AMBIENTE, 2015). O emprego deste curtametragem teve como intuito abordar as ameaças à Floresta pelo desmatamento, mineração e expansão agrícola, além de permitir uma discussão acerca do Decreto Presidencial 9.147, de 28 de agosto de 2017, que pretendia extinguir a RENCA (Reserva Nacional de Cobre e Associados). Neste local, há a sobreposição de sete Unidades de Conservação e duas Terras Indígenas, mostrando a barbárie do poder econômico para com os povos originários. Desta forma, os estudantes responderam ao seguinte questionamento:

"Quem são os responsáveis por implementar ações para acabar com as ameaças à Floresta Amazônica?"

Deste modo, se obteve como resultados quantitativos a Figura 2.

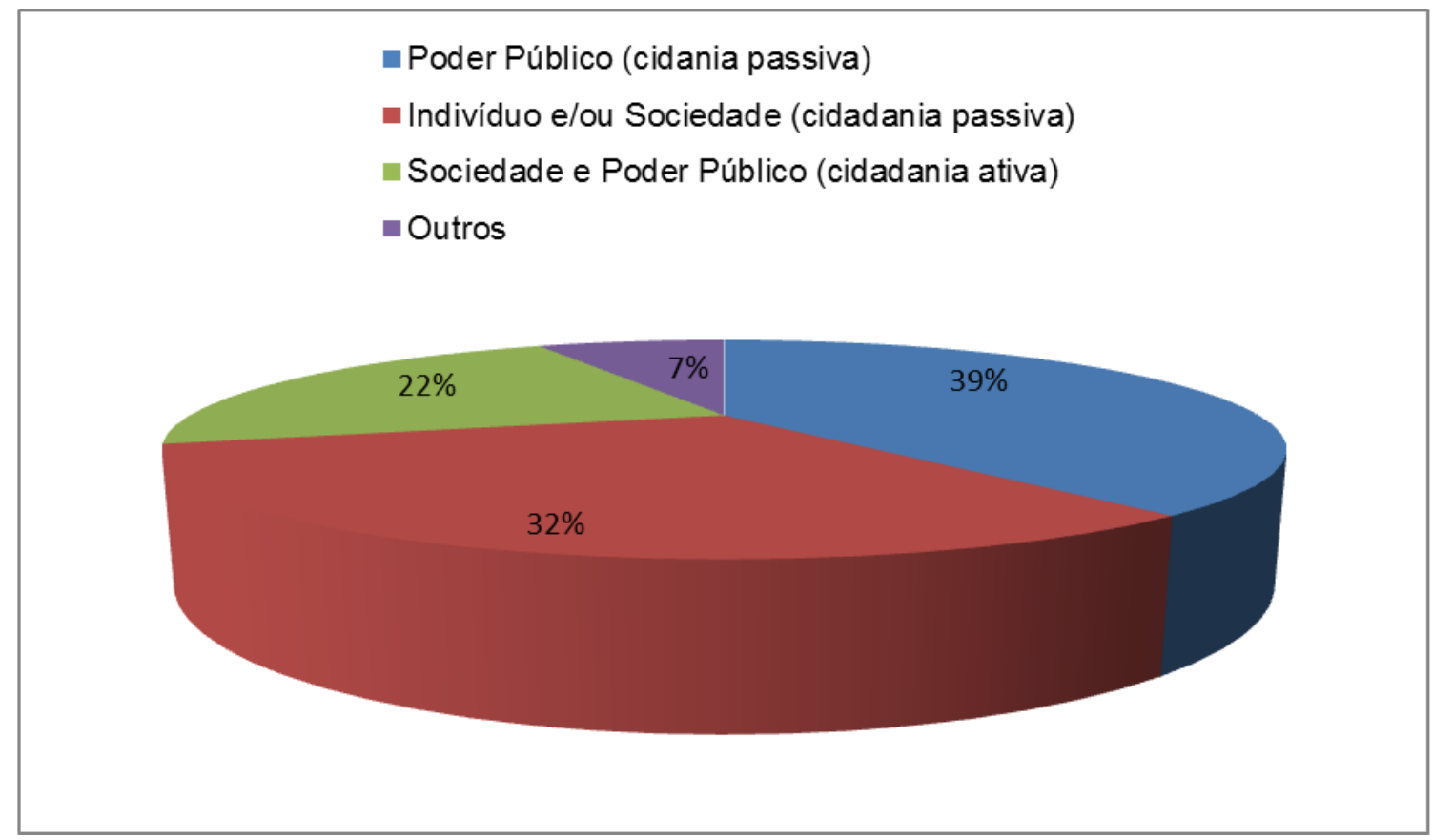

Figura 2: Categorização das respostas dos estudantes no curta-metragem "Rios Voadores".

Fonte: Autoria própria.

Por meio da Figura 2, se observa que a categoria "Poder Público" apresentou, em conjunto com "Indivíduo e/ou Sociedade", que caracterizam uma visão de cidadania passiva, $71 \%$ das respostas dos estudantes, enquanto que somente $22 \%$ apresentaram uma concepção de cidadania ativa. Nesta 
questão, 7\% das respostas não foram possíveis de ser enquadradas em qualquer categoria. Pode-se observar que a maioria das respostas atribuiu ao Poder Público a responsabilidade para a solução do problema, diferentemente da análise anterior.

A maioria das respostas foram categorizadas como "Poder Público", como se percebe na resposta do Aluno 3.6:

A população deve ter consciência das consequências do desmatamento, e o governo deveria tomar providências para acabar com essas ações.

Deste modo, mais uma vez o cidadão vê ações que permanecem apenas como tarefa a ser executada pelo Estado e, além disto, não se percebe a população como parte da solução dos problemas, ao se referir, no discurso do aluno, que os cidadãos não têm "consciência ambiental", como pode ser observado em outras respostas, exemplificadas a seguir (Aluno 3.2):

Deve-se conscientizar a população e abordar os riscos e consequências do ato.

Ainda como uma percepção passiva de cidadania, na categoria "Indivíduo e/ou Sociedade", onde sua maioria permanece com o pensamento de "parar de desmatar, de poluir e dar fim nas queimadas" (Aluno 2.3), exemplifica-se uma visão de Educação Ambiental Conservacionista, em que não se pretende compreender os fatores sociais, históricos e políticos envolvidos em um problema socioambiental (ANDRADE; TALAMONI, 2013).

Em termos da categoria "Sociedade e Poder Público", que caracteriza a cidadania ativa, se chama a atenção para a seguinte resposta (Aluno 3.8):

O responsável por essas atitudes é o governo, que está visando o lucro ao invés da preservação da Floresta. Para isso acabar, a população deve se unir e protestar, pois quando ela [a Floresta] não existir mais, irá ocorrer mudanças no clima de muitas regiões.

Durante a intervenção, se notou que a temática da Floresta Amazônica é conhecida pelos estudantes envolvidos, pois, de todos os curtas-metragens trabalhados, foi o que mais demonstrou uma percepção dos estudantes de uma cidadania ativa. Pode-se inferir que isso deve ter ocorrido devido à repercussão internacional da potencial extinção da RENCA que, além das petições para sua não efetivação em todo o país, teve como símbolo de luta a participação, no 
"Rock in Rio", de Sônia Guajajara, líder indígena brasileira, que foi ao palco reivindicar a demarcação de terras indígenas no Brasil e falar o quanto o governo de então estava dificultando o alcance dos direitos conquistados com muita luta e participação ativa da população indígena. Também se pode inferir outro fator, qual seja, ações que possam levar à degradação da Floresta Amazônica já estão consolidadas no imaginário popular. Este formato de questionário foi mais direto ao solicitar para o estudante a reflexão sobre os responsáveis por implementar as ações que garantissem os direitos ambientais da população, o que possibilitou melhor compreensão no momento de categorizar as frases e palavras-chave apresentadas pelos estudantes.

\section{Análise da percepção de cidadania pelos estudantes: curta metragem "São Paulo: a cidade dos rios invisíveis"}

Devido o município de llha Solteira ter se consolidado a partir de uma usina hidrelétrica com grande potencial de geração de energia e cuja malha hídrica possibilita às pessoas uma relação direta com seus rios, o curtametragem "São Paulo: a cidade dos rios invisíveis" foi aplicado para estimular a discussão acerca da relação do meio urbano com seus rios. O curta-metragem relaciona as enchentes que ocorrem no meio urbano com a canalização e tamponamento dos rios que já pertenciam a estes espaços sendo que, uma vez canalizados e tendo suas várzeas ocupadas por outros usos da terra, há um aumento do escoamento superficial das águas pluviais, ocasionando estes problemas socioambientais.

Segundo Bartalini (2006), do ponto de vista ambiental, esses rios se encontram em calamidade, pois apesar de existir legislação que protege as matas ciliares, há dificuldades históricas quanto à sua efetivação, tanto por problemas de ordem social, como a ocupação destas áreas por comunidades de baixa renda, devido à especulação imobiliária nos municípios, ou ainda por interesses econômicos na construção de loteamentos em Áreas de Preservação Permanente. Neste sentido, a pergunta trabalhada na discussão do curta-metragem foi:

"O que pode ser feito para que a cidade viva de forma mais harmônica com seus rios? Quem tem o papel de colocar isto em prática?".

As respostas, devidamente categorizadas de forma quantitativa, estão ilustradas na Figura 3. 


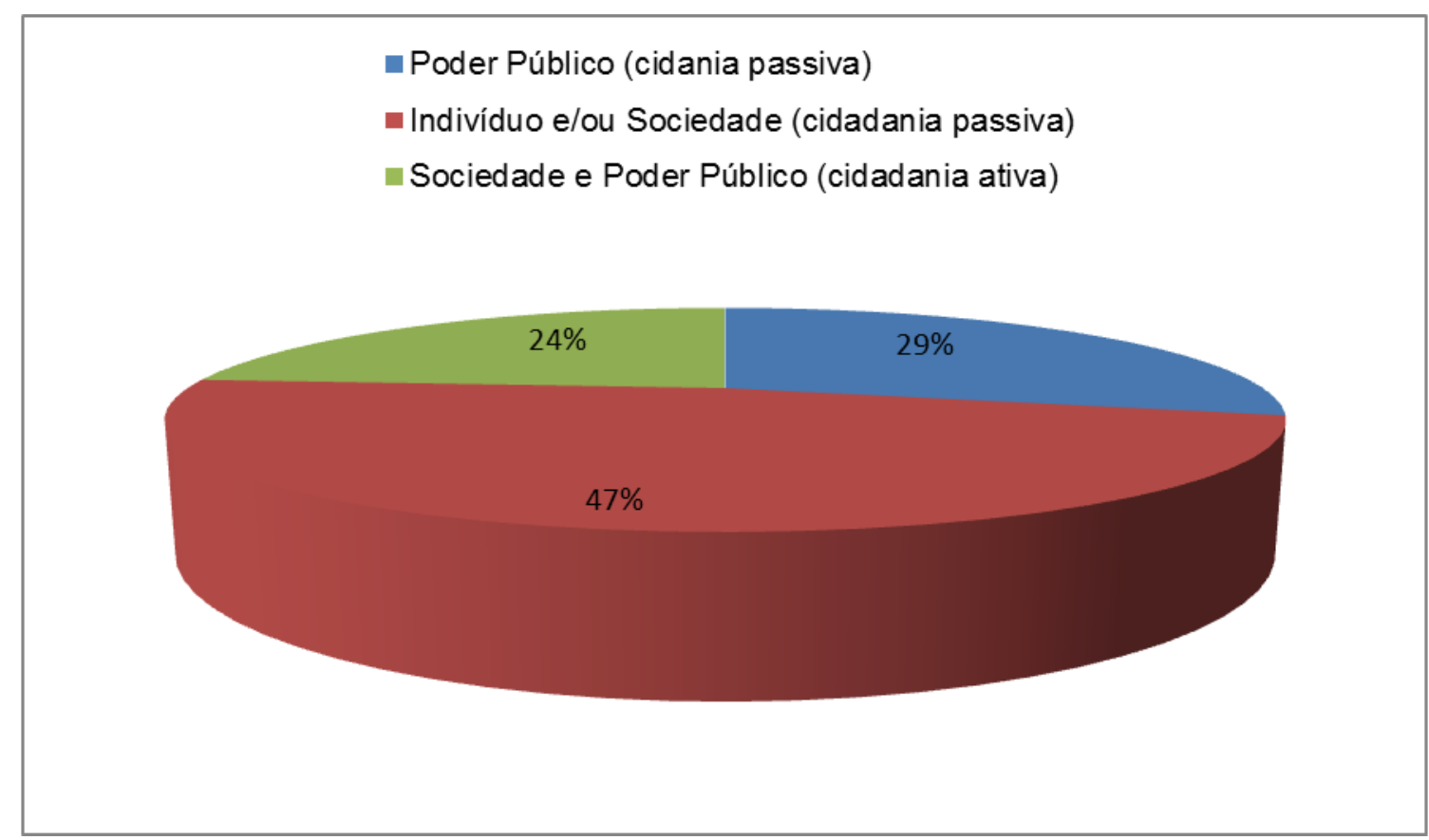

Figura 3: Categorização das respostas dos estudantes no curta-metragem "São Paulo: A cidade dos rios invisíveis". Fonte: Autoria própria.

Por meio da Figura 3, se observa que a categoria "Poder Público" apresentou, em conjunto com "Indivíduo e/ou Sociedade", que caracterizam uma visão de cidadania passiva, $76 \%$ das respostas dos estudantes, enquanto que somente $24 \%$ apresentaram uma concepção de cidadania ativa. Nota-se que, assim como o problema das áreas verdes urbanas, a temática "água" teve como principal ator responsável na solução de seus problemas, os indivíduos e a sociedade.

Analisando-se as respostas do questionário, se observa que as respostas estão relacionadas com ações como reformas em estruturas urbanas, além de educação e conscientização popular. Logo, se infere que os estudantes esperam que algum ente Público faça tal exercício. Pode-se perceber tal fato na resposta do Aluno 3.11:

Começar pela educação, mostrando para as crianças a importância dos rios. Quem deveria ter esse papel é a Prefeitura.

Ainda em termos de uma percepção de cidadania passiva, na categoria "Indivíduo e/ou Sociedade", que obteve o maior número de respostas, se observa a vertente de Educação Ambiental Conservacionista predominante no discurso dos estudantes, que valoriza excessivamente os processos de conscientização ambiental dos indivíduos, sem uma análise aprofundada das 
raízes dos problemas socioambientais (GUERRA; ABÍLIO, 2006). Nesta ótica, destaca-se também a seguinte resposta do Aluno 3.4:

Primeiramente, todos precisam ter a conscientização e começando a ensinar as crianças, pois, futuramente, vão ser elas as prejudicadas ou favorecidas. A sociedade como um todo.

Tal visão de Educação Ambiental que, segundo Andrade e Talamoni (2013), não se insere em uma reflexão aprofundada sobre o desenvolvimento social atrelado à crise ambiental, pressupõe a intocabilidade de alguns espaços protegidos, visando às gerações futuras. O Aluno 1.1 exemplifica esta percepção:

Preservá-los [os rios]. Os moradores [responsabilidade], diminuindo a poluição.

Já em termos de cidadania ativa, se obteve como resposta do Aluno 1.15, o seguinte:

Pode ser feito a preservação, a limpeza, e a sociedade quanto a Prefeitura tem que cumprir este papel.

Tal resposta remete ao protagonismo da sociedade civil e do Poder Público na resolução do problema abordado. No entanto, não simboliza aquilo que Carvalho (2004) denomina de leitores críticos do seu mundo, pois há uma ausência de conhecimento sobre as causas que levam à degradação dos rios. Contudo, pode-se observar a seguinte resposta do Aluno 3.10:

Somos nós que integramos a comunidade em uma conjunta ação com os políticos.

$\mathrm{Na}$ resposta ilustrada acima, se apresenta a visão de um sujeito modificador do seu meio que, segundo Loureiro (2004), Carvalho (2004) e Reigota (2004) valorizam a participação junto às forças sociais locais a partir da formação de uma consciência crítica, havendo a corresponsabilidade da Sociedade com o Poder Público na manutenção dos direitos e deveres ambientais. 


\section{Análise da percepção de cidadania pelos estudantes: curta-metragem "Cuidar das Borboletas: agricultura natural na região de Campinas"}

Este curta-metragem foi ministrado na instituição escolar com o objetivo de discutir problemas socioambientais derivados do modelo monocultor agrícola de desenvolvimento brasileiro, mostrando que os produtores orgânicos fazem parte de uma cadeia complexa de produção, triagem e relação vendedor-consumidor que beneficia a sociedade como um todo. Na produção de orgânicos, não há poluição do ar, água e solo, se comparado ao modelo agrícola convencional, tanto em termos de impactos ao meio quanto na qualidade do alimento, que é livre de agrotóxicos (BRASíLIA, 2005).

Durante a discussão sobre o tema, o mediador levou os estudantes a refletir sobre o modelo agrícola baseado na produção de orgânicos, que pode ser considerado mais sustentável do ponto de vista socioambiental, pois estimula uma gestão participativa, na qual não há concentração de renda e muito menos de poder, ao contrário do desenvolvimento agrícola convencional.

O curta-metragem foi produzido pela Articulação Nacional de Agroecologia, sendo o $21^{\circ}$ episódio da série, que exibe a implementação de um SAF (Sistema Agroflorestal), apoiado pelo Programa Ecoforte no período de 2013-2015, que se integra ao Plano Nacional de Agroecologia e Produção Orgânica (Planapo), do Ministério de Desenvolvimento Agrário, agora extinto. Neste sentido, a questão colocada aos estudantes foi:

"O que o país e você, enquanto cidadão, poderiam fazer para aumentar a produção de orgânicos?".

As respostas, devidamente categorizadas de forma quantitativa, estão ilustradas na Figura 4.

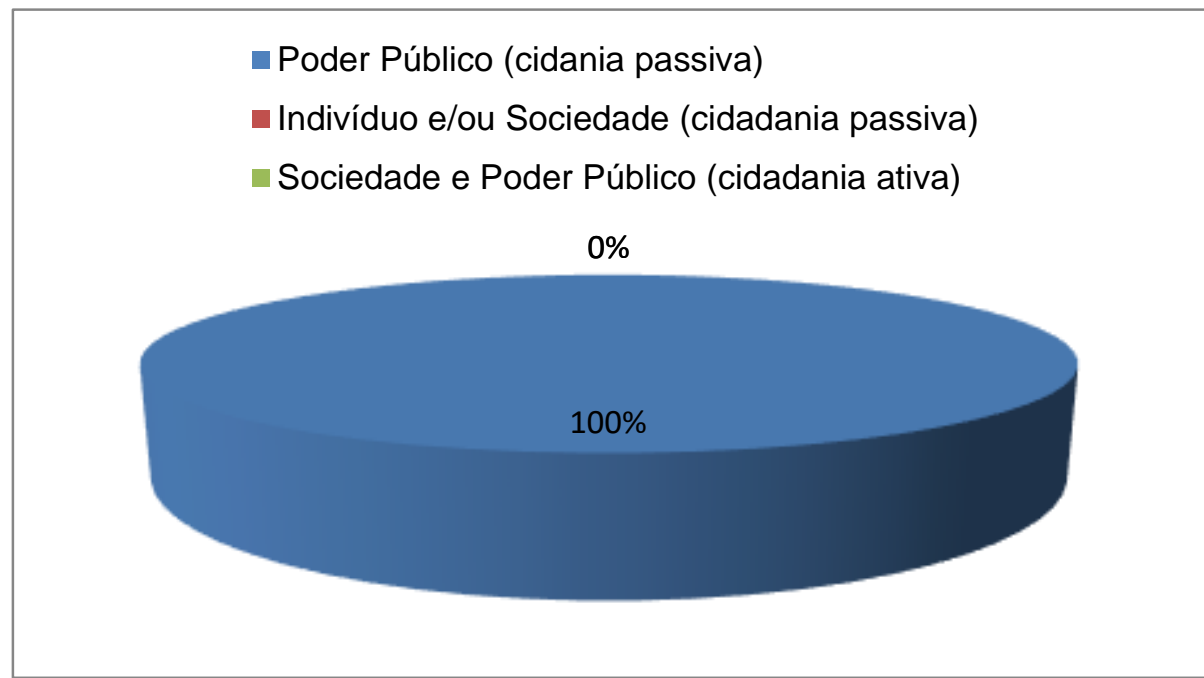

Figura 4: Categorização das respostas dos estudantes no curta-metragem "Cuidar das Borboletas: agricultura natural na região de Campinas". Fonte: Autoria própria. 
Por meio da Figura 4, se observa que todas as respostas foram categorizadas somente em "Poder Público", que caracteriza uma visão de cidadania passiva por parte dos estudantes.

Por meio da análise das respostas, é possível perceber o individualismo pautado nas ideias típicas do pensamento neoliberal que, segundo Karnal (2015), direciona os sujeitos à obtenção da prosperidade individual, o que os isenta da atividade cívica e participação política em suas comunidades. Deste modo, deixa-se à mercê do Poder Público uma tomada de ação visando o aumento da produção de sistemas orgânicos no país, como se observa na resposta do Aluno 2.2:

Políticas de conscientização e incentivo a formações de cooperativas, enfatizando a parte financeira (lucro).

Deste modo, a percepção de cidadania de caráter passivo predominou nas respostas, em que o indivíduo não se percebe como agente modificador do seu entorno e não se envolve na formulação de políticas públicas junto aos seus representantes, se isentando da participação na governança dos recursos naturais. Neste sentido, segundo Ribeiro (2015), o modelo econômico capitalista, responsável pela segregação social, acaba por fomentar na sociedade um modelo educacional acrítico e tradicional, sendo que sua predominância nos espaços formais e informais de ensino é um risco sempre eminente para a perda de direitos conquistados.

\section{Conclusão}

Como se pôde perceber neste artigo, a maioria dos estudantes que participou desta pesquisa apresentou um posicionamento de cidadania predominantemente passiva, concebendo seus direitos socioambientais como benesses concedidas pelo Estado. Deste modo, a participação na formulação de políticas públicas ou na forma de reivindicação de direitos é dada de modo individual, não se buscando modelos de associativismo para a de busca coletiva da conquista e manutenção de direitos historicamente conquistados. Deste modo, é possível que em uma democracia de baixa intensidade assim consolidada, onde a democracia participativa não se faz presente, os direitos sociais se encontrem constantemente em risco.

Os curtas-metragens proporcionaram que os debates realizados levassem os estudantes a refletir sobre a temática socioambiental, onde se discutiu alguns destes problemas de forma não conteudista, mas sim do ponto de vista da Educação Ambiental Crítica, o que pode ter facilitado, mesmo que em uma mínima percentagem, a fala de jovens que apresentaram uma percepção de cidadania ativa. Considera-se que, pela qualidade dos temas e dos curtas-metragens, que os estudantes tiveram a oportunidade de ouvir o 
lugar de fala de populações que passam por injustiças ambientais, tais como indígenas e assentados em projetos de reforma agrária, assim como tiveram a possibilidade de ouvir cientistas que apresentaram realidades que não são devidamente abordadas nos currículos escolares, como as áreas verdes urbanas ou os rios voadores da Floresta Amazônica.

Contudo, se a pesquisa se pautasse somente pelo conteúdo ministrado, é possível que as respostas estivessem mais relacionadas à vertente de EA Conservacionista, pois a literatura indica ser a forma de EA mais trabalhada nas instituições de ensino. Deste modo, a EA Crítica se mostra como a vertente onde é possível trabalhar questões de direitos e deveres ambientais, dado seu caráter emancipatório, o que, somado à ferramenta audiovisual, possibilita e enriquece as discussões em sala-de-aula.

Além do mais, a EA Crítica permite trabalhar a cidadania de modo a unir Educação e Ciências Políticas, principalmente com o conceito de cidadania ativa, pouco explorado em EA. Tal vertente só é possível ser trabalhada pela práxis de profissionais da educação que estejam comprometidos a auxiliar os estudantes na compreensão e transformação de seu meio. Neste sentido, há uma necessidade de desenvolver projetos pedagógicos nesta vertente, de modo a estimular nos educandos um posicionamento crítico perante os problemas enfrentados pela sociedade, o que se dá de forma gradual e contínua.

\section{Referências Bibliográficas}

ABÍLIO, F.J.P. Ética, Cidadania e Educação Ambiental. In: Andrade, M.O. (Coord.). Meio Ambiente e Desenvolvimento: bases para uma formação interdisciplinar. João Pessoa: Editora Universitária da UFPB, 2008.

ANDRADE, T.Y.I.; TALAMONI, J.L.B. A Educação Ambiental nas escolas municipais de Brotas (SP): análise de concepções e ações no contexto do programa Município Verde Azul. In: Anais do VII Encontro Pesquisa em Educação Ambiental (VII EPEA). Rio Claro: UNESP, p. 01-15, 2013.

BARDIN, L. Análise de Conteúdo. 2ª . reimp. da 1a. edição de 2011. São Paulo: Edições 70, 2011.

BARGOS, D.C.; MATIAS, L.F. Áreas Verdes Urbanas: Um Estudo de Revisão e Proposta Conceitual. Revista Soc. Bras. de Arborização Urbana, v. 6, n. 3, p.172-188, 2011.

BARTALINI, V. A trama capilar das águas na visão cotidiana. Revista Usp, n.70, p. 88-97, 2006.

BENEVIDES, M.V.M. Cidadania e Democracia. Lua Nova, n. 33, p. 5-17, 1994.

BRASÍLIA. Consumo sustentável: Manual de educação. Brasília: Consumers International/MMA/MEC/IDEC, 2005. 
CARVALHO, I.C.M. Educação Ambiental Crítica: nomes e endereçamentos da educação. Identidades da Educação Ambiental brasileira. Brasília: Ministério do Meio Ambiente, p. 13-24, 2004.

CINEMA E MEIO AMBIENTE. "Rios Voadores". Blog Cinema e Meio Ambiente. 2015. Disponível em: <http://cinemameioambiente.blogspot.com/>. Acesso em: 02 fev. 2019.

CINEMA E MEIO AMBIENTE. Rio Resiliente: Áreas Verdes Urbanas. Blog Cinema e Meio Ambiente. 2017. Disponível em: <http://cinemameio ambiente.blogspot.com/>. Acesso em: 25 fev. 2019.

CRUZ, A.B.; FERNANDES, G.W.R. Limites e possibilidades sobre o uso do vídeo documentário científico no Ensino de Física. In: Atas do IX Encontro Nacional de Pesquisa em Educação em Ciências (IX ENPEC). São Paulo: Águas de Lindóia, 2013.

DIÓGENES, J.E.N. Gerações ou dimensões dos direitos fundamentais? Revista Âmbito Jurídico. 2018. Disponível em:<http://www.ambitojuridico. com.br/site/?n link=revista artigos leitura\&artigo $i d=11750>$. Acesso em: 15 dez. 2018.

FERREIRA, H.M. A transversalidade nas aulas de Língua Portuguesa: A Educação Ambiental em questão. In: Anais do SILEL, v.3, n.1. Uberlândia: EDUFU, 2013.

GAVA, R.; XAVIER, W.S. Entre o Ensino e o Debate: o uso do documentário "The Corporation" como recurso didático na formação de administradores brasileiros. Revista Eletrônica de Gestão Organizacional, número especial I ENEPQ, p. 70-79, 2008.

GUERRA, R. A. T.; ABÍLIO, F.J.P. Educação Ambiental na escola pública. João Pessoa: Foxgraf, 2006.

IURCONVITE, A.S. Os direitos fundamentais: suas dimensões e sai incidência na Constituição Revista Âmbito Jurídico. 2018. Disponível em:< http://www.ambitojuridico.com.br/site/index.php?n link=artigos leitura pdf\&\%2 0artigo $\mathrm{id}=4528$. $>$ Acesso em: $15 \mathrm{dez} .2018$.

JACOBI, P. R. Educação Ambiental, cidadania e sustentabilidade. Cadernos de Pesquisa, n. 118, p. 189-205, 2003.

KARNAL, L. Revolução Americana. Estados Unidos, liberdade e cidadania. In: PINSKY, J.; PINSKY, C. B. (Coord.). História da cidadania. 6”. Ed., 2a reimpressão. São Paulo: Contexto, p. 135-157. 2015.

LASARA, L.F. O papel pedagógico dos documentários no Ensino de Ciências. 2013. Trabalho Final de Curso (Faculdade de Educação). Faculdade de Educação, Universidade de Brasília.

LIMA, G.A.B. Depoimentos em cena: do cinema às salas-de-aula. In: $\mathbf{X}$ Encontro Regional Sudeste de História Oral, São Paulo: Campinas, 2013. 
LINHARES, E.; REIS, P. A discussão de controvérsias sócio-científicas a partir de documentários em vídeo. In: MEMBIELA, P.; CASADO, N.; CEBREIROS, M.I. (Coord.) Retos e perspectivas no ensino das Ciências. Roma: Edita Educación. 2013.

LOUREIRO, C.F.B. Educar, participar e transformar em Educação Ambiental. Revista Brasileira de Educação Ambiental, n.0, p. 13-20, 2004.

MAESTRELLI, S.R.P.; FERRARI, N. O óleo de Lorenzo: o uso do cinema para contextualizar o ensino de genética e discutir a construção do conhecimento científico. Genética na Escola, n. 1, v. 2, p. 35-39, 2006.

MARICATTO, C. Educação Ambiental: conceitos e princípios. Belo Horizonte: FEAM, 2002.

MARQUES, L. Capitalismo e Colapso Ambiental. 2ª ${ }^{a}$ ed. São Paulo: Editora Unicamp, 2017.

MENEZES, S.F.; DUARTE, A.J.C. Reflexões sobre saberes e práticas em Saúde Ambiental a partir do documentário Boca de Lixo. Ciência \& Ensino, v.1, número especial, 2007.

MORIN, E. A cabeça bem-feita: Repensar a reforma, reformar o pensamento. $12^{\circ}$ ed. Rio de Janeiro: Bertrand Brasil. 2006.

NAPOLITANO, M. Como usar o cinema na sala de aula. 4ª ed. São Paulo: Contexto, 2010.

NEVES, I.C. O recurso ao documentário no processo de ensino-aprendizagem da Língua Inglesa no Ensino Superior. Revista Científica ESEC, n.7, p. 107119, 2013.

ODALIA, N. Revolução Francesa. A liberdade como meta coletiva. In: PINSKY, J.; PINSKY, C. B. (Coord). História da cidadania. 6a․ Ed., 2ª reimpressão. São Paulo: Contexto, p. 159-189. 2015.

OSCAR, S.C. Educação Ambiental no estado do Rio de Janeiro. Ver. Georgr. Acadêmica, v.1 n.1, p. 65-78, 2007.

PINSKY, J. Introdução. In: PINSKY, J.; PINSKY, C. B. (Coord.). História da cidadania. 6ª . Ed., 2ª reimpressão. São Paulo: Contexto, p.09-13. 2015.

RAMOS, E.C. Educação Ambiental: origens e perspectivas. Educar em Revista, v.17, n.18, p. 201-218, 2001.

REIGOTA, M.A.S. Cidadania e Educação Ambiental. Psicologia \& Sociedade, edição especial, v. 20, p. 61-69, 2008.

RIBEIRO, W.C. Meio Ambiente. Em busca da qualidade de vida. In: PINSKY, J.; PINSKY, C. B. (Coord.). História da cidadania. $6^{\underline{a}}$. Ed., $2^{\underline{a}}$ reimpressão. São Paulo: Contexto, p.399-417. 2015.

ROSA, P. R. S. O Uso dos Recursos Audiovisuais e o Ensino de Ciências. Caderno Catarinense de Ensino de Física, v. 17, n. 1, p. 33-49, 2000. 
SATO, M.; PASSOS, L. A. Biorregionalismo: identidade histórica e caminhos para a cidadania. In: LOUREIRO, C. F. B.; LAYRARGUES, P. P.; CASTRO, R. S. (Coord.). Educação Ambiental: repensando o espaço da cidadania. 4a São Paulo: Cortez, p. 221-252. 2008.

SAUVÉ, L. Uma cartografia das correntes em Educação Ambiental. Educação Ambiental: pesquisa e desafios, p. 17-44, 2005.

SEVERINO, A.J. Metodologia do Trabalho Científico. 23ạ. Edição. São Paulo: Cortez, 2007.

SINGER, P. Direitos Sociais. A cidadania para todos. In: PINSKY, J.; PINSKY, C. B. (Coord.). História da cidadania. 6ª ${ }^{2}$ Ed., $2^{\underline{a}}$ reimpressão. São Paulo: Contexto, p.190-263, 2015.

SORRENTINO, M. Educação Ambiental, participação e organização de cidadãos. Em Aberto, v.10, n.49, p.47-56, 1991.

TRISTÃO, M. Saberes e fazeres da Educação Ambiental no cotidiano escolar. Revista brasileira de Educação Ambiental, n.0, p.47-56, 2004.

VIEIRA, F.Z.; ROSSO, A. J. O cinema como componente didático da Educação Ambiental. Rev. Diálogo Educ., v. 11, n. 33, p. 547-572, 2011. 